\title{
IDENTIFIKASI PEWARNA MERAH K3 (CI 15585) DALAM PRODUK KOSMETIK SEDIAAN PERONA MATA SECARA LC- MS/MS
}

\author{
Riana Suastari Rahayu ${ }^{1 *}$, Iryanti Eka Suprihatin ${ }^{1,2}$, Wiwik Susanah Rita ${ }^{1,2}$ \\ ${ }^{1}$ Magister Kimia Terapan, Pascasarjana Universitas Udayana, Jl. PB. Sudirman, Denpasar, Bali \\ ${ }^{2}$ Jurusan Kimia FMIPA, Universitas Udayana, Bukit Jimbaran, Badung, Bali \\ *puturiana81@gmail.com
}

\begin{abstract}
ABSTRAK : Identifikasi merah K3 dalam sediaan perona mata secara LC-MS/MS dilakukan untuk mengkonfirmasi keberadaannya yang sering kali ditemukan dalam konsentrasi kecil. Metode spektrofotometeri UV-VIS dan HPLC tidak cukup untuk mengkonfirmasi keberadaan merah K3 yang dinyatakan positif dengan metode KLT. Optimasi metode dilakukan pada kondisi spektrometer massa dan sistem kromatografi cair yang berlaku pada LC-MS/MS sebelum dilakukan proses identifikasi. Hasil optimasi menunjukkan identifikasi merah K3 dengan LC-MS/MS menggunakan teknik ionisasi elektrospray (ESI) dan sistem Multiple Reaction Monitoring (MRM) pada mode ionisasi negatif. Ion prekursor pada $\mathrm{m} / \mathrm{z}$ 375 dan ion produk pada m/z 204, 80, 140 digunakan untuk identifikasi.
\end{abstract}

Kata kunci : Merah K3, LC-MS/MS, ESI, MRM, optimasi.

ABSTRACT : Identification of red dye (CI 15585) using LC-MS/MS in eye shadow was performed to confirm its presence in very low concentrations. The UV-VIS spectrophotometry and HPLC are not sufficient to confirm the presence of red dye identified by the TLC. The optimation of the method was carried out under the condition applicable to LC-MS / MS prior to identification process. Optimation results show that red dye can be identified with LC-MS/MS using electrospray ionization technique (ESI) and Multiple Reaction Monitoring (MRM) system under negative ionization mode. The precursor ion at $\mathrm{m}$ / z 375 and the product ions at m / z 204, 80, 140 are used for identification.

Keywords: Red dye (CI 15585), LC-MS/MS, ESI, MRM, optimation, validation

\section{PENDAHULUAN}

Peningkatan temuan produk kosmetik yang mengandung merah $\mathrm{K} 3$ berdasarkan pengawasan BPOM pada semester I tahun 2016 mendorong laboratorium untuk mengembangkan metode yang efektif untuk mendeteksi keberadaan merah K3 pada produk kosmetik. Merah K3 adalah salah satu pewarna yang dilarang penggunaannya karena kekhawatiran terhadap efek samping karsinogenik yang ditimbulkan. Metode KLT digunakan untuk skrining awal. Apabila sampel mempunyai Rf yang sejajar dengan baku pembanding, analisis dilanjutkan dengan spektrofotometer UV-
VIS. Merah K3 ditemukan dalam konsentrasi kecil sehingga menunjukkan panjang gelombang yang sama dengan baku tetapi tidak memberikan serapan yang maksimal. Analisis juga dilakukan dengan KCKT dan diperoleh hasil sampel yang dicurigai memberikan waktu retensi yang sama dengan baku akan tetapi luas puncak sangat kecil bila dibandingkan dengan baku. Analisis dengan metode spektrofotometer UV-VIS dan KCKT tidak cukup untuk mengkonfimasi keberadaan merah K3 dalam sampel.

Belum banyak penelitian yang dilakukan untuk mengidentifikasi 
keberadaan merah K3 dalam produk kosmetik. Sedangkan untuk zat warna dilarang lainnya seperti rhodamin B, telah banyak diteliti keberadaannya pada produk kosmetik. Identifikasi rhodamin B lebih mudah karena dengan metode KLT apabila bercak rhodamin B diamati di bawah sinar UV akan berfluorosensi oranye yang sangat spesifik. Telah dilakukan identifikasi rhodamin B pada sediaan lipstik (Tangka et $a l ., 2012)$ dengan metode KLT dan pada kosmetik pemerah pipi dan eyeshadow (Rachmawati et al., 2014) dengan metode KLT dan KCKT. Analisis kimia dan kajian resiko terhadap merah $\mathrm{K} 3$ yang dilarang dalam produk cat wajah dilakukan oleh Wilhem et al., (2015). Hal ini dilatar belakangi oleh penggunaan cat wajah untuk melukis bendera kebangsaan pada wajah selama piala dunia berlangsung. Metode analisis yang digunakan untuk identifikasi adalah KLT, Spektrofotometri UV-VIS, KCKT, dan ${ }^{1} \mathrm{H}-\mathrm{NMR}$, sedangkan untuk uji kuantitatif menggunakan LC-MS/MS.

Berdasarkan latar belakang tersebut, penelitian kali ini melakukan identifikasi merah K3 dengan menggunakan LCMS/MS. Metode analisis dengan LCMS/MS menggunakan detektor spektrometer massa yang menganalisis senyawa berdasarkan pengukuran bobot molekul per muatan $(\mathrm{m} / \mathrm{z})$ dan akan diperoleh hasil analisis berupa pola fragmentasi yang spesifik. Oleh karena itu metode ini diharapkan lebih selektif dan akurat karena setiap senyawa memiliki berat molekul dan fragmentasi yang berbeda. Sediaan kosmetik yang dipilih untuk diidentifikasi adalah perona mata, karena sebagai pewarna dekoratif beragam warna yang digunakan untuk mempercantik lebih banyak bernuansa merah sehingga dicurigai ada penambahan merah K3 di dalamnya.

Penelitian ini bertujuan untuk memperoleh kondisi optimum LC-MS/MS yang dapat digunakan untuk mengidentifikasi merah K3 dalam perona mata serta dapat memenuhi persyaratan uji validasi metode

\section{PERCOBAAN}

\section{Bahan dan peralatan}

Bahan-bahan yang digunakan dalam penelitian ini adalah standar merah K3 (CI 15585) BPFI, N,N-Dimetil formamid, Asam ortofosfat, Asam formiat, Metanol, dan Akuabides.

Alat-alat yang digunakan dalam penelitian ini adalah labu ukur, pipet volume, gelas beker, pipet mikro, neraca analitik, LC-MS/MS Shimadzu type 8030, kolom Phenomenex Luna C18 dengan dimensi kolom 4,6 x $150 \mathrm{~mm}$ dan ukuran partikel 3,5 $\mu \mathrm{m}$, kolom Acquity UPLC BEH dengan dimensi kolom 2,1 x $100 \mathrm{~mm}$ dan ukuran partikel 1,7 $\mu \mathrm{m}$, detektor MS triple quadropole, penyaring membran $0,2 \mu \mathrm{m}$.

\section{Optimasi Kondisi Spektrometer Massa}

Optimasi awal dilakukan untuk mengetahui mode ionisasi yang digunakan. Proses scanning awal dilakukan pada quadrupole 1 (Q1) tanpa menggunakan kolom menggunakan baku standar merah K3 dengan konsentrasi 10 ppm pada mode ionisasi positif dan negatif. Menggunakan teknik ionisasi elektrospray (ESI) dan sistem Multiple Reaction Monitoring (MRM) akan diperoleh informasi nilai $\mathrm{m} / \mathrm{z}$ dari ion prekursor dan ion produk. Instrumen LC-MS/MS Shimadzu type 8030 secara otomatis akan menentukan energi yang dibutuhkan oleh Q1, Q2, dan Q3 untuk memfragmentasi ion prekursor menjadi ion produk.

\section{Optimasi Sistem Kromatografi Cair}

Optimasi dilakukan dengan menggunakan kolom Phenomenex Luna C18 dengan diameter 4,6 x $150 \mathrm{~mm}$ dan ukuran partikel $5 \mu \mathrm{m}$ yang dikondisikan dengan fase gerak asam formiat $0,2 \%$ dalam air (eluen A) dan asam formiat $0,2 \%$ dalam metanol (eluen B) dengan laju alir $0,4 \mu \mathrm{L} /$ menit dan volume penyuntikan 10 $\mu \mathrm{L}$ dengan teknik analisis program binary gradien yang mana pada menit $10^{-2} ; 50 \%$ A, menit $3 ; 30 \%$ A, dan menit 3,01-4; 50\% A. 


\section{Validasi Metode}

\section{a. Spesifisitas}

Pelarut, larutan matriks sampel, larutan spiked sampel, dan larutan standar merah K3 diinjeksikan, kemudian dilihat retention time dan nilai $\mathrm{m} / \mathrm{z}$ hasil fragmentasi ion prekursor menjadi ion produk.

\section{b. Batas Deteksi (LOD)}

Pengukuran LOD dilakukan pada larutan standar dengan rentang konsentrasi 0 - 0,458 ppm. Perhitungan batas deteksi dilakukan dengan menggunakan metode perhitungan berdasarkan simpangan baku residual.

\section{c. Akurasi}

Penetapan akurasi dilakukan dengan cara spiking yaitu penambahan baku pada sampel dengan konsentrasi baku yang ditambahkan sebesar 1 ppm, kemudian dihitung \% recovery.

\section{d. Presisi}

Nilai presisi dinyatakan dengan repeatability yang diperoleh dari pengukuran luas puncak sebanyak 6 kali pengulangan pada kondisi yang sama terhadap larutan standar merah K3.

\section{e. Linearitas}

Penetapan linearitas dilakukan dengan mengukur luas puncak kromatogram dari larutan standar merah K3 dengan variasi konsentrasi antara 0,5 - 5 ppm dengan pengulangan sebanyak 3 kali, sehingga akan diperoleh diperoleh korelasi antara luas puncak (y) dengan konsentrasi ( $\mathrm{x}$ ) berupa persamaan garis.

\section{HASIL DAN PEMBAHASAN}

\section{Optimasi Kondisi Spektrometer Massa}

Optimasi spektrometer massa meliputi mode ionisasi yang digunakan, energi yang dibutuhkan oleh Q1 untuk memperoleh ion prekursor yang spesifik, energi yang dibutuhkan oleh collision cell untuk fragmentasi ion prekursor dan energi yang dibutuhkan oleh Q3 untuk memperoleh ion produk yang spesifik. Kondisi optimum dari keseluruhan parameter tersebut, yang ditunjukkan dengan terdeteksi dan terfragmentasinya analit dengan baik akan sangat menentukan keberhasilan identifikasi selanjutnya sehingga kondisi tersebut sangat penting untuk dicapai.

Optimasi awal dilakukan untuk mengetahui mode ionisasi yang digunakan untuk memberikan fragmentasi dengan intensitas yang maksimal. Proses scanning awal dilakukan pada quadrupole 1 (Q1) menggunakan mode ionisasi positif dan negatif. Pada optimasi awal dilakukan tanpa menggunakan kolom, sehingga fase gerak dialirkan langsung ke detektor. Optimasi dilakukan dengan menggunakan standar merah K3 pada konsentrasi 10 ppm.

Hasil optimasi menunjukkan bahwa mode ionisasi negatif memberikan puncak dengan intensitas maksimal pada fragmentasi $\mathrm{m} / \mathrm{z} 375$, yang dapat dilihat pada Gambar 1 (A).
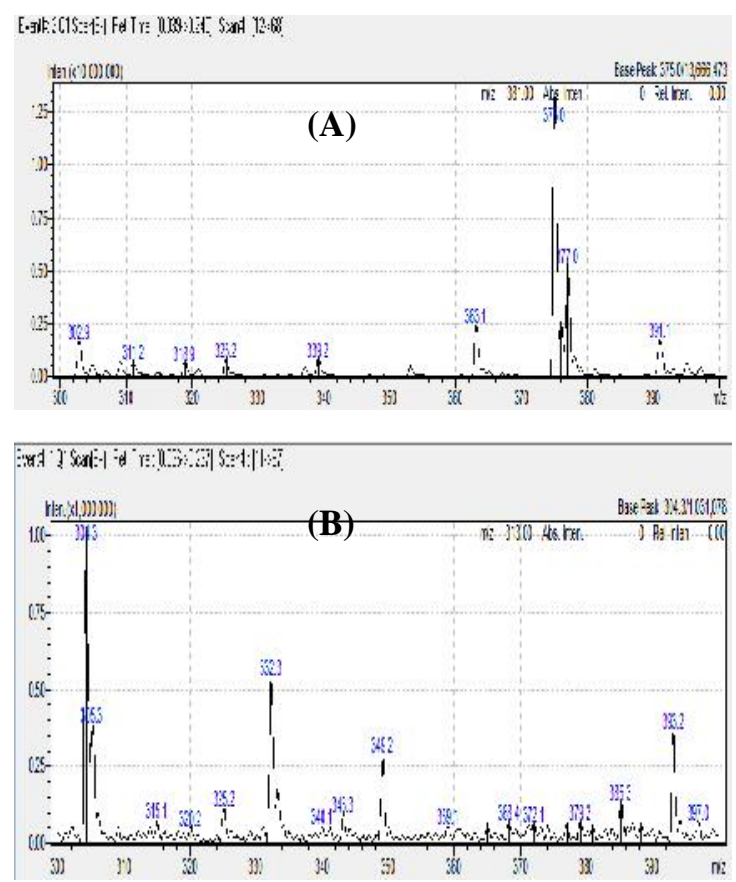

Gambar 1. Spektra hasil ionisasi Merah K3 pada mode ionisasi negatif (A) dan ionisasi positif (B). 
Puncak tertinggi yang muncul pada mode ionisasi positif dengan nilai $\mathrm{m} / \mathrm{z}$ 304,3 (Gambar 1 B) memiliki intensitas dengan perbandingan sepersepuluh dari puncak yang muncul pada mode ionisasi negatif dengan nilai $\mathrm{m} / \mathrm{z}$ 375. Hal ini menunjukkan ionisasi yang maksimal terjadi pada mode ionisasi negatif.

Spektrum massa standar merah K3 menunjukkan puncak yang paling tinggi intensitasnya pada m/z 375 (Gambar 1A). Puncak tersebut terjadi karena senyawa merah K3 dengan berat molekul 888,6 terionisasi dengan cara melepas atom
Barium. Selanjutnya terjadi proses deprotonasi pada gugus hidroksil yang terikat pada cincin naphtalen, yang mana terjadi proses resonansi yang stabil dan kuat sehingga melepas 1 (satu) atom Hidrogen dan diperoleh berat molekul 375 yang identik dengan nilai $\mathrm{m} / \mathrm{z}$ 375. Merah K3 dengan berat molekul yang cukup besar yaitu 888,6 menyebabkan proses ionisasi yang terjadi hanya dengan melepas ikatan Barium. Proses ionisasi ini dapat dilihat pada Gambar 2.

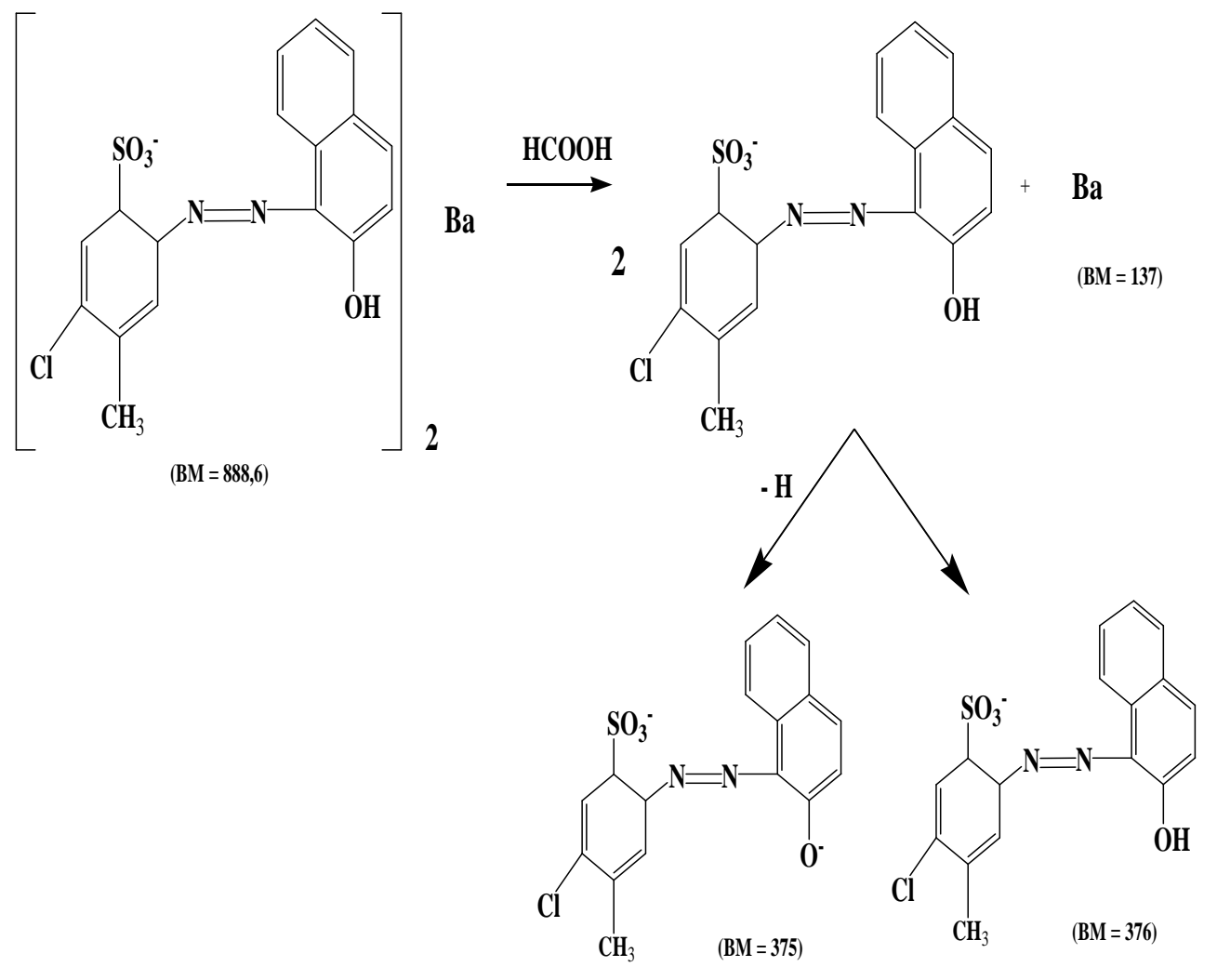

Gambar 2. Proses ionisasi Merah K3

Puncak dengan intensitas tertinggi yaitu pada m/z 375 tersebut kemudian ditetapkan sebagai ion prekursor untuk analisis selanjutnya. Optimasi selanjutnya menggunakan sistem MRM. Teknik ini mampu memilah-milah fragmentasi dari ion prekursor secara spesifik sehingga yang terdeteksi hanya ion produk dengan nilai m/z tertentu dengan Q1, Q2 dan Q3 pada posisi on. Secara otomatis alat akan menentukan energi yang diperlukan untuk memperoleh fragmentasi dari ion prekursor menjadi ion produk dengan nilai $\mathrm{m} / \mathrm{z}$ tertentu yang spesifik. Ion dengan nilai $\mathrm{m} / \mathrm{z}$ 


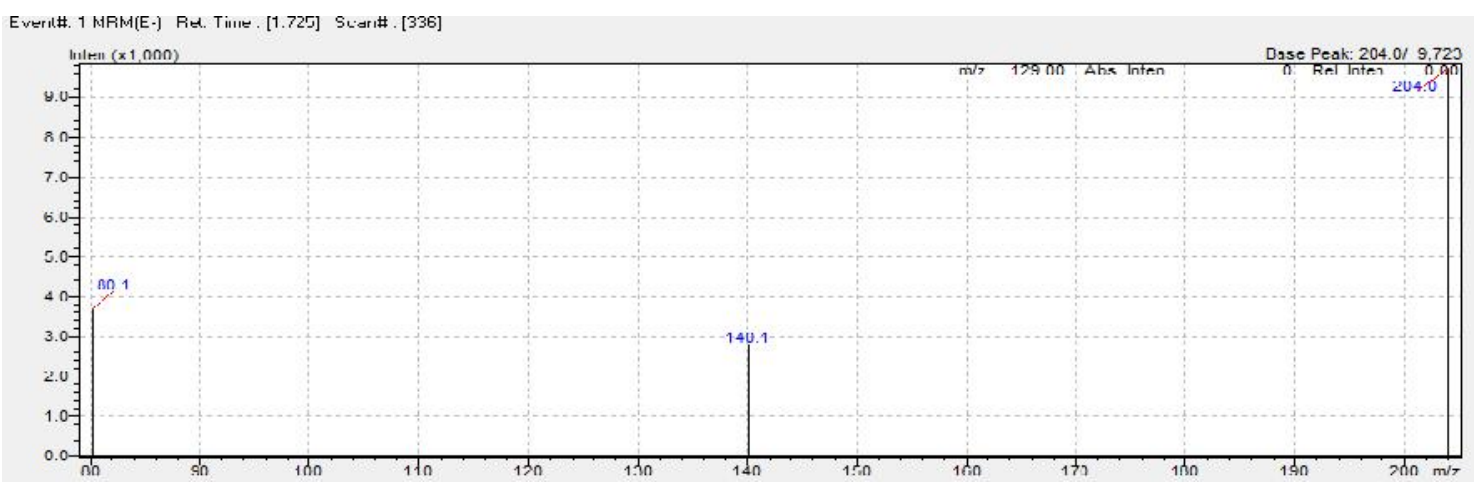

Gambar 3. Hasil fragmentasi ion prekursor

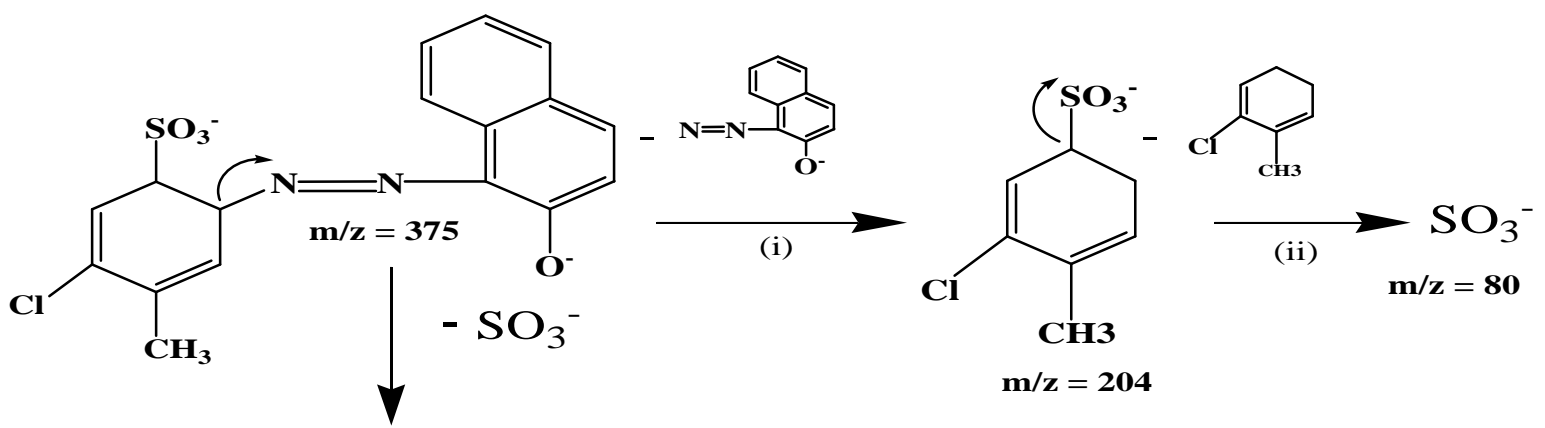

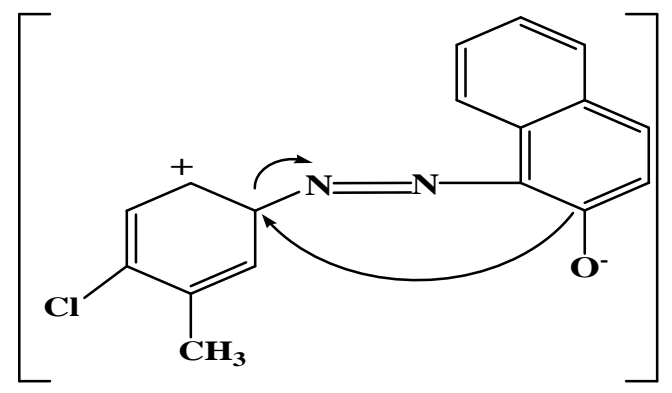

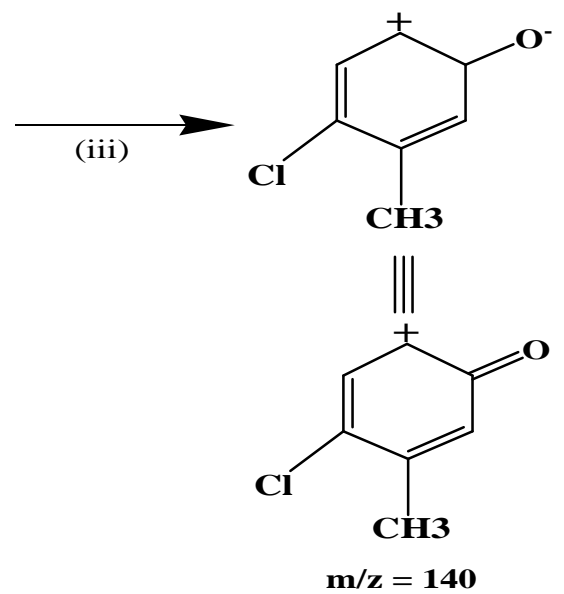

Gambar 4. Hasil fragmentasi ion prekursor

375 yang telah ditetapkan sebagai ion prekursor setelah difragmentasi menghasilkan 3 pecahan ion dengan nilai $\mathrm{m} / \mathrm{z}$ 204, 80 dan 140. Nilai m/z 204 dan 80 mempunyai intensitas yang tertinggi. Hasil fragmentasi ion prekursor dapat dilihat pada Gambar 3.

Fragmentasi ion prekursor dengan nilai m/z 375 menjadi m/z 204 diperoleh dari putusnya ikatan yang bersebelahan dengan $\mathrm{N}_{2}$. Fragmentasi tertinggi kedua 
yaitu pada $\mathrm{m} / \mathrm{z} 80$ yang diperoleh dari lepasnya ion belerang trioksida $\left(\mathrm{SO}_{3}{ }^{-}\right)$. Fragmentasi terendah dengan nilai m/z 140 diperoleh dari putusnya ikatan yang bersebelahan dengan $\mathrm{N}_{2}$ yang diikuti dengan penataan ulang gugus hidroksil. Hasil fragmentasi ion prekursor dapat dilihat pada Gambar 4. Ion prekursor yang telah ditetapkan dengan nilai $\mathrm{m} / \mathrm{z} 375$ di scan dengan memberikan energi sesuai dengan manual instrumen untuk memperoleh ion produk. Energi yang dibutuhkan berbeda-beda untuk setiap ion produk yang diperoleh, yang ditentukan oleh instrumen secara otomatis. Energi yang dibutuhkan pada proses fragmentasi ion prekursor menjadi ion produk dapat dilihat pada Tabel 1.

\section{Optimasi Sistem Kromatografi Cair}

Optimasi yang dilakukan pada sistem kromatografi cair adalah pada penggunaan kolom dan fase gerak yang digunakan. Kolom mempunyai peran penting dalam kromatografi karena berfungsi untuk memisahkan ion atau molekul dari suatu larutan. Kolom pertama yang digunakan untuk optimasi adalah jenis Phenomenex Luna $\mathrm{C} 18$ dengan dimensi kolom 4,6 x $150 \mathrm{~mm}$ dan ukuran partikel 3,5 $\mu \mathrm{m}$. Pemisahan menggunakan kolom jenis tersebut tidak memberikan hasil yang optimal karena tidak dapat memisahkan senyawa merah K3 yang ditunjukkan dengan tidak adanya puncak yang muncul.

Optimasi kemudian dilanjutkan dengan menggunakan kolom Acquity UPLC BEH dengan dimensi kolom 2,1 $\mathrm{x}$ $100 \mathrm{~mm}$ dan ukuran partikel 1,7 $\mu \mathrm{m}$. Kolom jenis ini juga merupakan kolom C18 akan tetapi memiliki ukuran partikel yang lebih kecil. Kolom tersebut digunakan dengan pertimbangan ukuran partikelnya lebih kecil sehingga akan memberikan luas permukaan yang jauh lebih besar. Semakin besar luas permukaan akan meningkatkan interaksi antara kolom dengan analit yang melewatinya. Terbukti optimasi menggunakan kolom jenis tersebut memberikan hasil yang lebih baik, dilihat dari munculnya puncak yang terpisah dengan baik pada menit 1,6. Pemisahan dengan kolom jenis Phenomenex Luna C18 dan Acquity UPLC BEH dapat dilihat pada Gambar 5

Optimasi juga dilakukan pada komposisi fase gerak yang digunakan. Fase gerak yang digunakan disesuaikan sifatnya dengan analit yang akan diidentifikasi. Asam formiat yang ditambahkan pada fase gerak metanol dan air digunakan untuk mengioniasi analit yang akan diidentifikasi. Ionisasi dapat dilakukan pada mode + (positif) dan - (negatif), yang mana untuk mode positif ditambahkan sejumlah kecil asam formiat untuk membatu terjadinya protonasi dari molekul sampel sedangkan untuk mode - (negatif) ditambahkan sejumlah kecil larutan basa seperti ammonia atau amin untuk deprotonasi. Optimasi awal mengunakan fase gerak asam formiat $0,2 \%$ dalam metanol (A) dan asam formiat $0,2 \%$ dalam air (B) dengan komposisi bergradien (Tabel ).

Tabel 1. Kondisi Optimum Spektrometer

\begin{tabular}{cccc}
\multicolumn{4}{c}{ Massa } \\
Nilai m/z & Q1 (V) & CE (V) & Q3 (V) \\
\hline 204 & 20 & 26 & 12 \\
80 & 20 & 50 & 24 \\
140 & 19 & 34 & 14 \\
\hline
\end{tabular}

Tabel 2. Komposisi Fase Gerak Bergradien

\begin{tabular}{ccc}
\hline $\begin{array}{r}\text { Waktu } \\
\text { (menit) }\end{array}$ & $\begin{array}{c}\text { \% Eluen A (Asam } \\
\text { formiat } 0,2 \% \\
\text { dalam metanol) }\end{array}$ & $\begin{array}{c}\text { \%Eluen B (Asam } \\
\text { formiat } 0,2 \% \\
\text { dalam air) }\end{array}$ \\
\hline 0,01 & 50 & 50 \\
3,00 & 30 & 70 \\
3,01 & 50 & 50 \\
4,00 & 50 & 50 \\
4,01 & & STOP \\
\hline
\end{tabular}




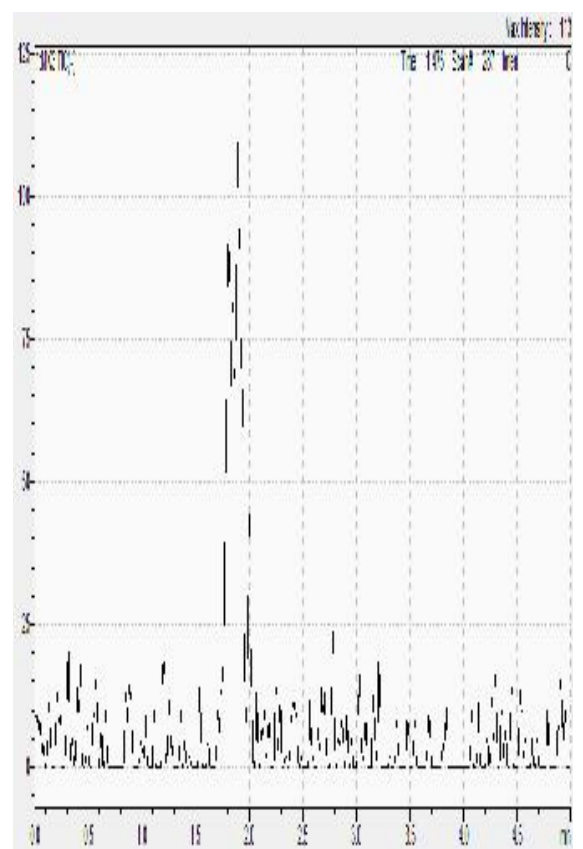

A

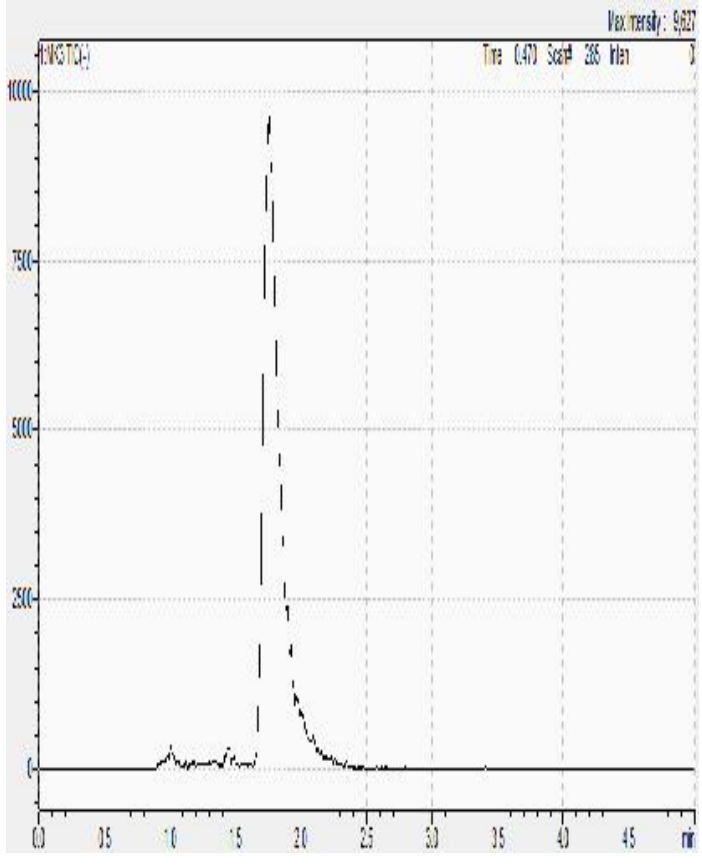

B

Gambar 5. Pemisahan dengan kolom jenis Phenomenex Luna C18 (A) dan Acquity UPLC $\mathrm{BEH}(\mathrm{B})$

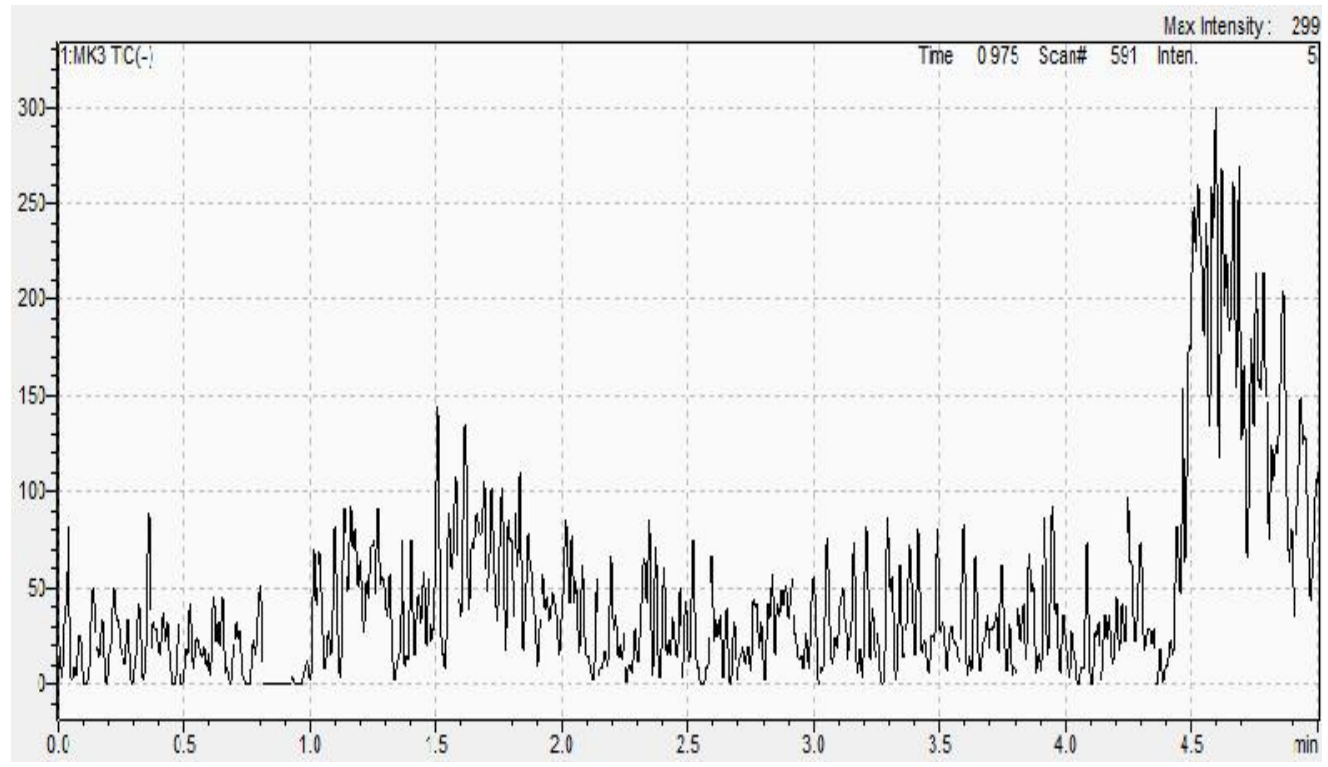

Gambar 6. Hasil pemisahan dengan komposisi fase gerak bergradien

Komposisi fase gerak bergradien seperti ditunjukkan pada Tabel 2, tidak mampu memisahkan senyawa merah K3. Diperkirakan fase gerak dengan komposisi yang maksimal pada $50: 50$ tidak mampu mendorong senyawa merah K3 yang tertahan pada kolom. Spektra massa hasil pemisahan merah K3 dengan fase gerak bergradien dapat dilihat pada Gambar 6 . 
Komposisi fase gerak selanjutnya ditingkatkan secara bertahap dan diperoleh hasil pemisahan yang maksimal yang ditunjukkan dengan puncak yang terpisah dengan baik pada komposisi fase gerak dengan perbandingan 9:1. Hasil pemisahan merah K3 dengan berbagai komposisi fase gerak dapat dilihat pada Gambar 7.

\section{KESIMPULAN}

Kondisi optimum instrumen LCMS/MS untuk identifikasi merah K3 menggunakan teknik ionisasi elektrospray (ESI) dan sistem MRM dengan mode ionisasi negatif. Energi yang diperlukan berbeda-beda untuk memperoleh fragmentasi ion prekursor menjadi ion produk. Metode ini dapat diaplikasikan untuk identifikasi merah K3 pada produk kosmetik sediaan perona mata yang beredar di pasaran.

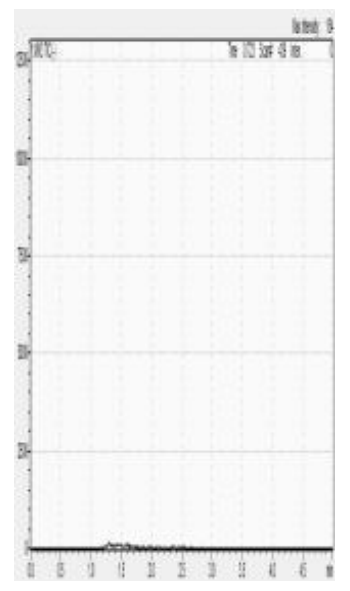

$75: 25$

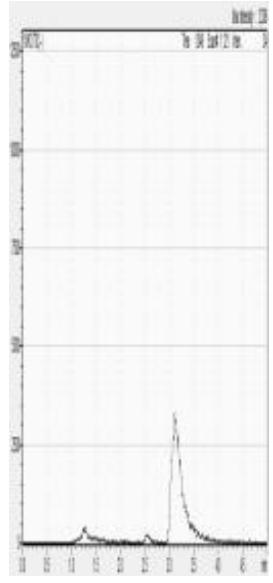

$80: 20$

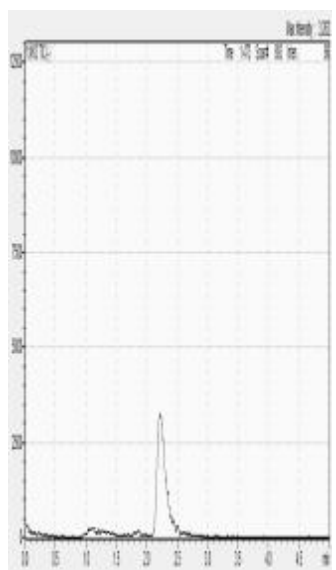

$85: 15$

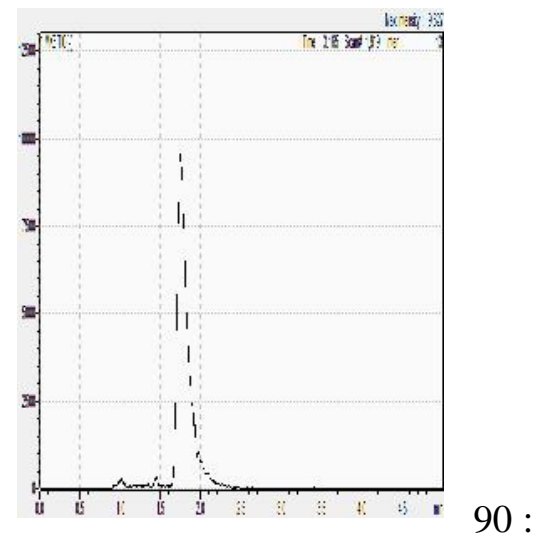

10

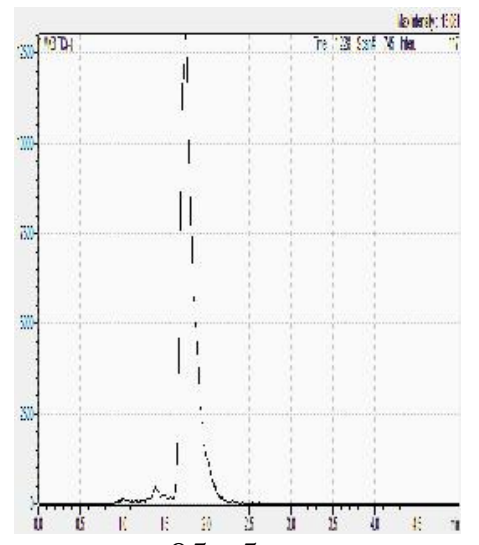

$95: 5$

Gambar 7. Hasil pemisahan Merah K3 dengan variasi komposisi fase gerak A : B 


\section{UCAPAN TERIMA KASIH}

Pada kesempatan ini penulis ingin mengucapkan terima kasih kepada Prof. Dr. Drs. I Made Dira Swantara, M.Si., Dr. Dra. Ni Made Suaniti, M.Si., Dr. Drs. Manuntun Manurung, M.S., yang telah memberikan masukan dan saran untuk menyempurnakan tesis dan penyusunan jurnal ini.

\section{DAFTAR PUSTAKA}

[1] Association of Official Analytical Chemist, 2012. Official Methods of Analysis 2012, Guidelines for Standard Method Performance Requirements, Appendix F.

[2] ICH, 2005. Validation of Analytical Procedures : Text and Methodology, ICH, Harminosed Tripartite Guideline, 9.
[3] Kepala Badan Pengawas Obat dan Makan Republik Indonesia, 2015. Peraturan Kepala Badan POM RI Nomor 19 Tahun 2015 tentang Persyaratan Teknis Kosmetika, Jakarta.

[4] Murni S., 2016. Serbuan Kosmetik Berbahaya Tersedia https ://sufrizaltanjung.wordpress.com, Diakses tanggal 31 Maret 2016.

[5] Stolker A.A.M., Dijkmaan E., Niesing W., Hogendoorn E.A., 2009. Identification of Residues by LC/MS/MS According to the New European Union Guidelines, National Institute for Public Health and the Environment, Netherlands.

[6] Tangka J., Pojoh J. A., Hasan H. A. M., 2012. Identifikasi Rhodamin B Pada Sediaan 